Article

\title{
Interzeolitic Transformation of Clinoptilolite into GIS and LTA Zeolite
}

\author{
Renata C. F. de Lima, Daniele da Silva Oliveira and Sibele B. C. Pergher *
}

check for updates

Citation: de Lima, R.C.F.; Oliveira D.d.S.; Pergher, S.B.C. Interzeolitic Transformation of Clinoptilolite into GIS and LTA Zeolite. Minerals 2021, 11, 1313. https://doi.org/10.3390/ $\min 11121313$

Academic Editors: Tamara Đorđević, Natalia V. Zubkova and Igor Djerdj

Received: 11 October 2021

Accepted: 22 November 2021

Published: 25 November 2021

Publisher's Note: MDPI stays neutral with regard to jurisdictional claims in published maps and institutional affiliations.

Copyright: (c) 2021 by the authors. Licensee MDPI, Basel, Switzerland. This article is an open access article distributed under the terms and conditions of the Creative Commons Attribution (CC BY) license (https:/ / creativecommons.org/licenses/by/ $4.0 /)$.
Molecular Sieves Laboratory (Labpemol), Instituto de Química, Universidade Federal do Rio Grande do Norte, Natal 59078-970, Brazil; renata.freire.014@ufrn.edu.br (R.C.F.d.L.); daniele.silva.oliveira.094@ufrn.edu.br (D.d.S.O.)

* Correspondence: sibele.pergher@ufrn.br

\begin{abstract}
A natural clinoptilolite zeolite was transformed into other zeolites of greater industrial interest, such as zeolites with GIS and LTA structures. The synthesis conditions were studied, and the interzeolitic transformation was characterized by X-ray diffraction (XRD), X-ray fluorescence (FRX), Fourier transform infrared spectroscopy (FTIR), and scanning electron microscopy (SEM). From the results, it was possible to observe that the GIS and LTA zeolites were successfully synthesized. Furthermore, the results revealed that a synthesis time of 4 days was enough to obtain the GIS structure, and $4 \mathrm{~h}$ was sufficient to obtain LTA. The interzeolitic transformation can be explained by the RBU (Ring Building Unit) approach using C4 units from the HEU topology. The use of clinoptilolite in the synthesis of other zeolites is an innovative, economically viable, and environmentally sustainable process that exploits a material that exists in large quantities and is still little explored by industry.
\end{abstract}

Keywords: clinoptilolite; eco-friendly synthesis; zeolite LTA; zeolite GIS

\section{Introduction}

Clinoptilolite is a natural zeolite belonging to the Heulandite group, with a $\mathrm{Si} / \mathrm{Al}$ ratio $\geq 4$, and is a sedimentary zeolite found in great quantity in nature [1-6].

Although clinoptilolite is abundant in nature, natural zeolites have limitations for commercial use due to impurities in their composition and variations in crystal uniformity. Furthermore, as natural zeolites have lower purity, they are mainly used to treat effluents due to their high cation exchange capacity [7] and animal feed additives [8].

Consequently, synthetic zeolites are more commercially used than natural zeolites due to their better uniformity in composition, high purity, and the possibility of modeling their properties to optimize them for specific industrial applications.

To reduce the production costs of synthetic zeolites, alternative sources of silicon and aluminum have been used. High-quality synthetic zeolites can be synthesized using a wide range of alternative sources, including natural aluminosilicates such as clays [8-19], natural zeolites [20,21], diatomite [22,23], and waste resources [24-32].

Thus, the synthesis of zeolites produced from clinoptilolite presents an attractive option mainly concerning cost efficiency. Clinoptilolite is a good candidate as a starting material for the production of zeolites of great industrial interest, such as GIS and LTA zeolites $[20,21]$. In these previous studies, $\mathrm{NaP}$ zeolites were obtained using clinoptilolite and sonochemical synthesis [20]. Zeolite A coatings were obtained using natural zeolites, mainly clinoptilolite [21].

GIS and LTA zeolites can be used in different applications, mainly based on their ionexchange properties. Commercially, LTA zeolite is primarily used as an additive to laundry detergent [33], since alternative building materials, such as sodium tripolyphosphate and trisodium phosphate, are declining in popularity due to problems with the eutrophication of watercourses [34]. In addition to traditional LTA zeolite applications in water softening opportunities, LTA zeolites have been used for catalyst processes, membrane separation, 
effluent treatment, and antimicrobial treatment [24]. On the other hand, GIS zeolites have a wide range of applications as a catalyst and adsorbents [35] and in exchange and adsorption of metal ions $\left(\mathrm{Ca}^{2+}, \mathrm{Mg}^{2+}\right)$ [36]. Furthermore, they also have a capacity for the adsorption of nonionic surfactants, which could improve the stability of detergent formulations [37].

The use of clinoptilolite zeolites as an alternative source of $\mathrm{Si}$ and $\mathrm{Al}$ in the synthesis of zeolites is an innovative, economically viable, and environmentally sustainable process that exploits materials found in large quantities, and that is still little used in industry. Thus, the objective of this work was to use clinoptilolite as an alternative source in the synthesis of GIS and LTA zeolites, varying the synthesis conditions.

\section{Materials and Methods}

Clinoptilolite RCB (lot 221), supplied by Celta Brasil [38], São Paulo, Brazil, was used in this work.

\subsection{Standard Zeolite Synthesis LTA and FAU}

LTA synthesis was performed using a procedure described by IZA (International Zeolite Association) [39]. In the synthesis of standard LTA-type zeolite, initially, a solution was prepared using $3.71 \mathrm{~g}$ of sodium hydroxide (98\%) and $59.82 \mathrm{~g}$ of $\mathrm{H}_{2} \mathrm{O}$. After complete dissolution, the solution was divided into two fractions of equal volumes: in the first fraction, $4.63 \mathrm{~g}$ of sodium aluminate was added, and in the second fraction, $3.01 \mathrm{~g}$ of aerosil silica was added. After homogenizing both, the first fraction was poured into the second fraction, and the system was agitated for approximately $30 \mathrm{~min}$. Finally, the formed gel was transferred to a Teflon autoclave lined with stainless steel, where crystallization occurs in a static medium at $100{ }^{\circ} \mathrm{C}$ for $3 \mathrm{~h}$ and $6 \mathrm{~h}$.

FAU synthesis was performed using a procedure adapted from Giannento [40]. Sodium hydroxide $(3.11 \mathrm{~g}, 98 \%)$, sodium aluminate $(2.69 \mathrm{~g})$, and colloidal silica $(28.44 \mathrm{~g}$, $30 \%$ in $\mathrm{H}_{2} \mathrm{O}$ ) were mixed under agitation for approximately $30 \mathrm{~min}$. The formed gel was left at room temperature for 3 days, and on the third day, it was transferred to a stainless steel-lined Teflon autoclave, where crystallization occurs in a static medium at $100{ }^{\circ} \mathrm{C}$ for a period of 4 to 8 days.

The samples were coded with the nomenclature ZPxa, where Z = LTA or FAU; P refers to refiring a standard synthesis; $x$ is the number of hours or days used in the synthesis; and $\mathrm{a}$ is the unit in hours $(\mathrm{h})$ or days $(\mathrm{d})$. For the sample, LTAP3h is the material obtained by LTA standard synthesis after $3 \mathrm{~h}$ of crystallization, and FAUP8d is the material obtained by FAU standard synthesis after 8 days of crystallization.

\subsection{Synthesis of the FAU Zeolite with Clinoptilolite}

The procedure was adapted from standard FAU zeolite synthesis [40]. Initially, a sodium hydroxide solution was prepared with $3.43 \mathrm{~g}$ of $\mathrm{NaOH}$ and $33.71 \mathrm{~g} \mathrm{of} \mathrm{H}_{2} \mathrm{O}$. After complete dissolution, the solution was divided into two fractions of equal volumes: in the first fraction, $2.84 \mathrm{~g}$ of sodium aluminate was added, and in the second fraction, $11.86 \mathrm{~g}$ of the clinoptilolite RCB (lot 221) and $7.58 \mathrm{~g}$ of $\mathrm{H}_{2} \mathrm{O}$ were added. After the homogenization of both, the first fraction was transferred into the second fraction, and the system was kept under agitation for $30 \mathrm{~min}$. The gel formed was left at room temperature for 3 days, and on the third day, it was transferred to a stainless steel-lined Teflon autoclave, where crystallization occurs in a static medium at $100{ }^{\circ} \mathrm{C}$ for a period of 1 to 8 days.

The obtained materials from this methodology are of GIS structure, not FAU.

\subsection{Synthesis of the LTA Zeolite with Clinoptilolite}

The procedure was adapted from standard LTA zeolite synthesis [39]. Initially, a solution was prepared using $1.18 \mathrm{~g}$ of sodium hydroxide $(98 \%)$ and $29.91 \mathrm{~g}$ of $\mathrm{H}_{2} \mathrm{O}$. After complete dissolution, the solution was divided into two fractions of equal volumes: in the first fraction, $1.87 \mathrm{~g}$ of sodium aluminate was added, and in the second fraction, $2.07 \mathrm{~g}$ of Clinoptilolite RCB LOT 221 was added. After the homogenization of both, the first 
is transferred into the second and keeps the system under agitation for approximately $30 \mathrm{~min}$. Finally, the gel formed is transferred to a stainless steel-lined Teflon autoclave, where crystallization occurs in a static medium at $100^{\circ} \mathrm{C}$ for a period of 1 to $6 \mathrm{~h}$.

The samples were coded with the nomenclature ZCxa, where $\mathrm{Z}=$ LTA or GIS; C refers to clinoptilolite; $x$ is the number of hours or days used in the synthesis; and a is the unit in hours (h) or days (d). LTAC3h is the material obtained by LTA synthesis using clinoptilolite after $3 \mathrm{~h}$ of crystallization, and GISC8d is the material obtained by GIS synthesis using clinoptilolite after 8 days of crystallization.

\subsection{Material Characterization}

X-ray diffraction patterns were obtained from powders using a Bruker D2Phaser diffractometer (Bruker, Billerica, Massachusetts, USA) equipped with a Lynxeye detector, copper radiation $(\mathrm{CuK} \alpha, \lambda=1.54 \AA)$ and a Ni filter, with a current of $10 \mathrm{~mA}$ and voltage of $30 \mathrm{kV}$. Data were collected at a high angle in a $2 \theta$ degree range from 5 to $50^{\circ}$, with a $0.1 \mathrm{~s}$ acquisition time and $0.01^{\circ}$ step size.

Through the XRD results, it was possible to calculate the percentage of relative crystallinity of the samples through the sum of the areas of the chosen peaks $\left(9.91^{\circ} ; 11.24^{\circ}\right.$; $22.40^{\circ} ; 27.88^{\circ} ; 30.10^{\circ}$; and $32.04^{\circ}$ for the LTA zeolite) for the analyzed material divided by the sum of the areas of the same peaks of the standard sample, which is assumed to be $100 \%$ crystalline, according to Equation (1).

$$
\% \text { Crystallinity }=\frac{\sum \text { peaks areas from synthesized sample }}{\sum \text { peaks areas from standard sample }} \times 100
$$

Chemical analysis was performed using X-ray fluorescence spectrometry (FRX), where an electron beam emitted through a cathodic source allows the identification of atomic species. This analysis was performed on a Bruker S2 Ranger apparatus (Bruker, Billerica, MA, USA) using Pd or Ag anode max radiation, with a $50 \mathrm{~W}$ power, a maximum voltage of $50 \mathrm{kV}$, a maximum current of $2 \mathrm{~mA}$, and an XFlash ${ }^{\circledR}$ silicon drift detector (Bruker, Billerica, MA, USA). The samples were placed on polypropylene support, and measurements were carried out in a He atmosphere.

Absorbance spectra were obtained in the mid-infrared region from 4000 to $400 \mathrm{~cm}^{-1}$ with a resolution of $4 \mathrm{~cm}^{-1}$ and 64 scans using a Shimadzu IRAffinity-1 Fourier transform infrared spectrophotometer (Shimadzu, Kyoto, Japan). For analysis, samples were prepared using solid $\mathrm{KBr}$ as a dispersing agent $(1 \% \mathrm{~m} / \mathrm{m})$, homogenized with a mortar and then submitted to compression by applying a pressure of $80 \mathrm{kN}$ for $2 \mathrm{~min}$.

For scanning electron microscopy, a TESCAN MIRA3 FEG-SEM instrument (Tescan, Brun, Czech Republic) was used. First, the samples were placed on a thin carbon strip attached to a stub. Afterward, a thin-layer metallization procedure was used to apply a gold film to make the sample a good electron conductor and to thus produce an image with quality and resolution. Finally, various magnifications were used to obtain the images.

\section{Results}

\subsection{Standard Zeolite Synthesis}

LTA and FAU standard zeolites were synthesized, and their X-ray patterns are shown in Figures 1 and 2. To certify the crystal structure of the zeolites obtained, the International Zeolite Association-IZA database [39] was used. The LTA (ICSD-00-039-0222) and FAU (ICSD-00-043-0168) crystalline phases were obtained.

The standard zeolites' chemical composition and $\mathrm{Si} / \mathrm{Al}$ ratio are presented in Tables 1-4 with the synthesized materials for comparison purposes. Additionally, Figures 4 and 7 show the IR spectra of the standard materials.

\subsection{FAU Zeolite Synthesis with Clinoptilolite}

The samples obtained by the FAU synthesis procedure using clinoptilolite show the GIS phase (ICSD-01-071-0962), as shown in Figure 3. 


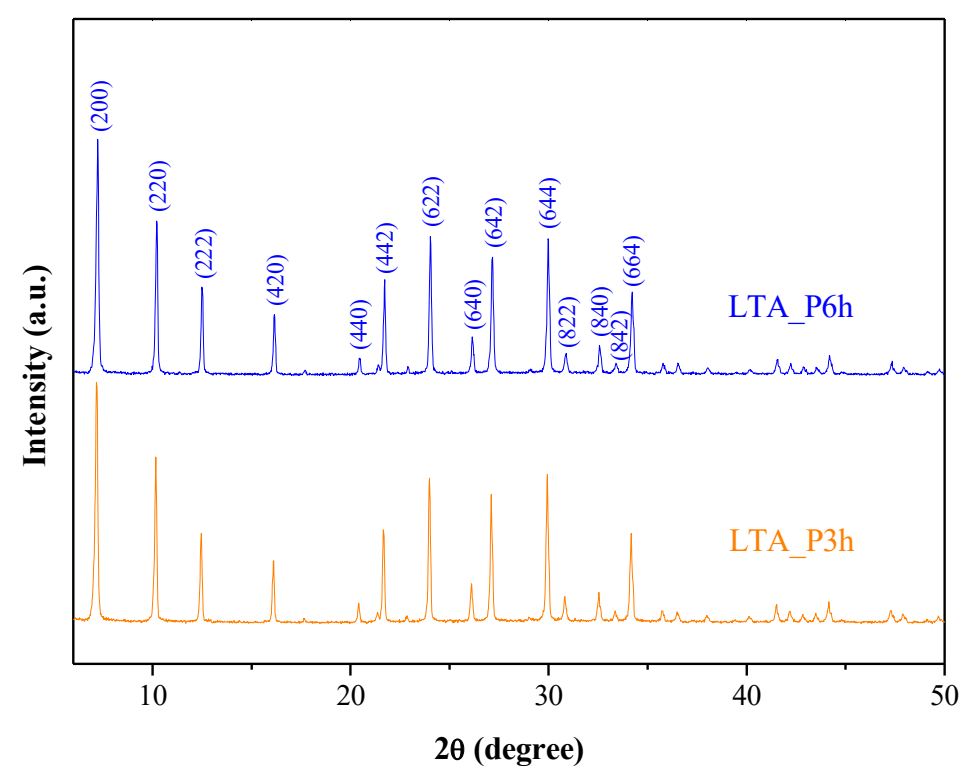

Figure 1. Standard LTA zeolite diffractograms.

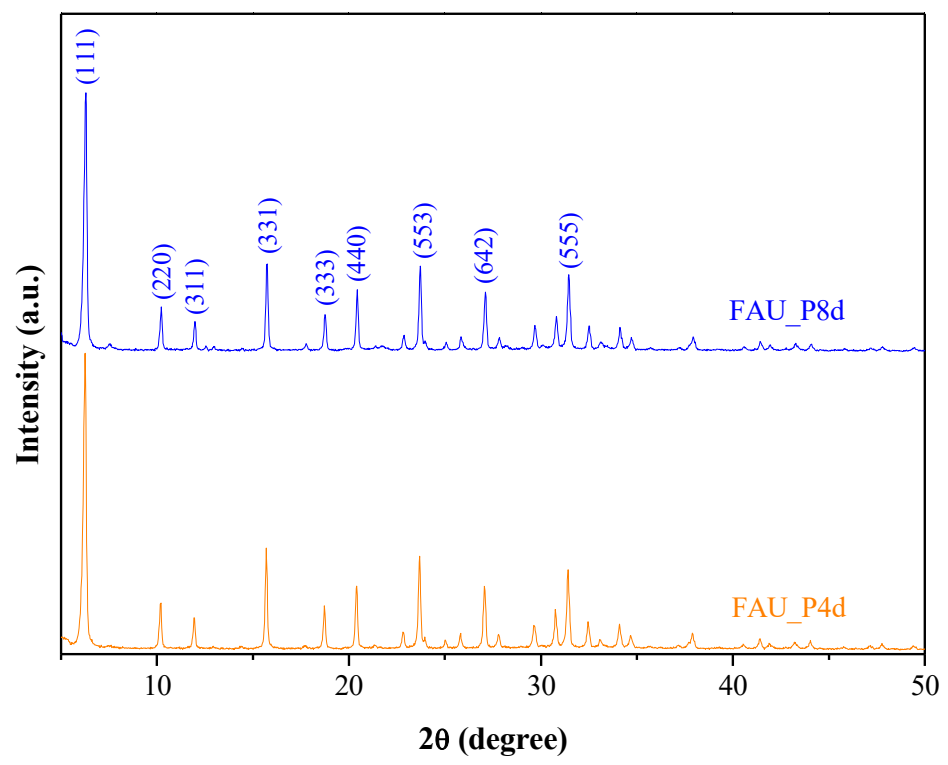

Figure 2. Standard FAU zeolite diffractograms.

Figure 2 shows that it was possible to obtain the standard FAU zeolite in 4 and 8 days. These zeolites showed FAU crystalline phases according to the position of their peaks compared to that of the IZA standard [39]. The GIS zeolite structure is obtained when we apply clinoptilolite as raw material in this synthesis methodology (Figure 3). The GIS zeolite has a more stable structure (phase) than the FAU zeolite, and its synthesis times were favorable for transforming clinoptilolite into this phase (more stable material) according to the Ostwald rule of successive transformations [41].

FRX analysis showed that the analyzed samples were aluminosilicates, and silicon and aluminum were the main elements present in these zeolites, as seen from the results in Table 1. Other elements typical of natural zeolites, such as $\mathrm{K}, \mathrm{Fe}, \mathrm{Mg}$, $\mathrm{Ca}$, and $\mathrm{Na}$, were also observed, with $\mathrm{Ca}, \mathrm{K}, \mathrm{Mg}$, and $\mathrm{Na}$ probably being the structural compensation cations. In the synthesized zeolites (standard and from clinoptilolite), $\mathrm{Na}$ exists as a principal compensation cation.

Table 2 shows the Si / Al molar ratio and synthesis yield values for standard zeolites and samples synthesized from clinoptilolite. The Si/ Al ratio of FAU zeolites and GIS4d and 
GIS8d samples decreases compared to that of clinoptilolite, because they are zeolites with different structures with different $\mathrm{Si} / \mathrm{Al}$ ratios. The lower $\mathrm{Si} / \mathrm{Al}$ ratios indicate that some silica must remain in solution; consequently, the synthesis yield will not achieve $100 \%$.

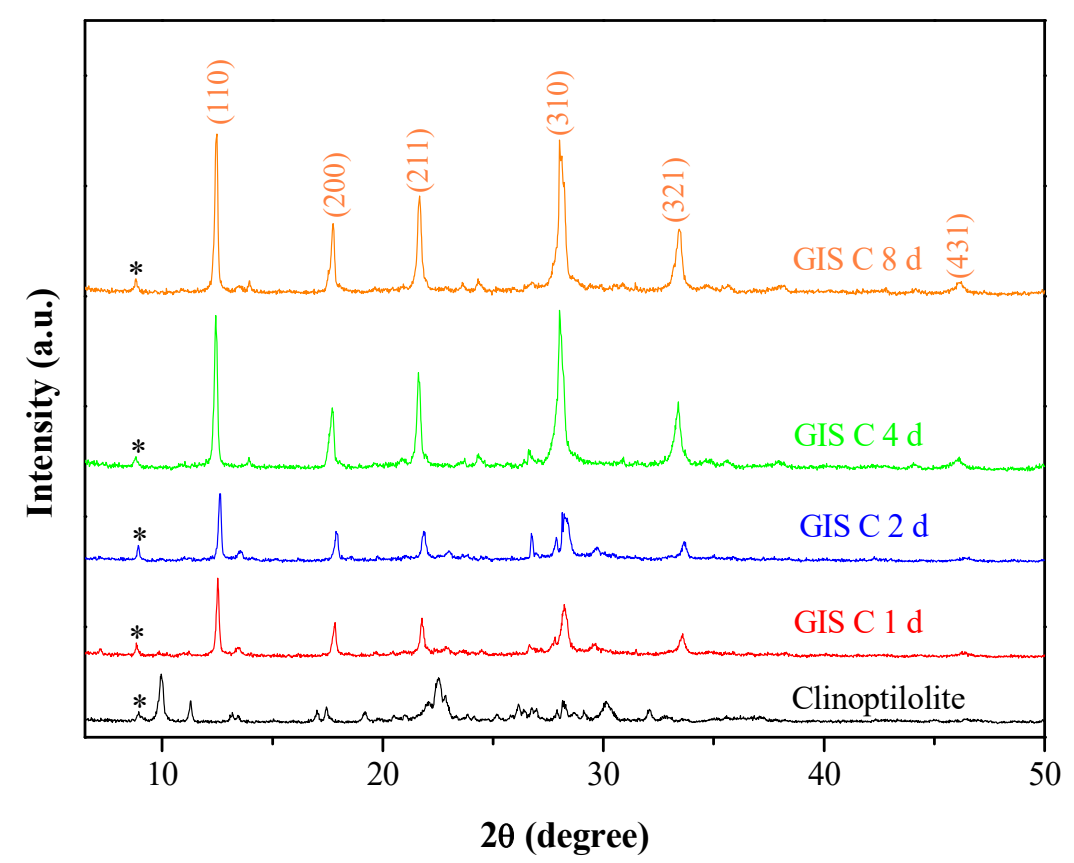

Figure 3. Diffractograms of GIS zeolites from clinoptilolite ( ${ }^{*}$ is an unidentified phase).

Table 1. Chemical composition (FRX) of standard FAU zeolites and GIS zeolites from clinoptilolite.

\begin{tabular}{cccccc}
\hline Oxide & Clinoptilolite & FAUP4d & FAUP8d & GISC4d & GISC8d \\
\hline $\mathrm{SiO}_{2}(\%)$ & 72.29 & 68.06 & 68.24 & 56.78 & 56.36 \\
$\mathrm{Al}_{2} \mathrm{O}_{3}(\%)$ & 12.80 & 21.45 & 20.67 & 23.66 & 24.11 \\
$\mathrm{~K}_{2} \mathrm{O}(\%)$ & 4.47 & 0.02 & n.d. & 3.76 & 3.49 \\
$\mathrm{CaO}(\%)$ & 4.09 & n.d. & n.d. & 3.30 & 3.13 \\
$\mathrm{SO}_{3}(\%)$ & 0.12 & 0.18 & 0.18 & 0.07 & 0.08 \\
$\mathrm{Fe}_{2} \mathrm{O}_{3}(\%)$ & 2.30 & 0.09 & 0.08 & 1.86 & 1.72 \\
$\mathrm{MgO}_{\mathrm{Ng}}(\%)$ & 2.10 & 1.50 & 1.60 & 1.60 & 1.90 \\
$\mathrm{Na}_{2} \mathrm{O}(\%)$ & 1.30 & 8.40 & 9.00 & 8.40 & 8.70 \\
Others (\%) & 0.53 & 0.32 & 0.26 & 0.55 & 0.53 \\
\hline
\end{tabular}

n.d. $=$ non detected.

Table 2. Si / Al molar ratio values and synthesis yield of standard FAU zeolites and GIS zeolites from clinoptilolite.

\begin{tabular}{ccc}
\hline Sample & Si/Al Ratio & $\begin{array}{c}\text { Synthesis Yield * } \\
\%(\mathrm{~m} / \mathrm{m})\end{array}$ \\
\hline Clinoptilolite & 4.79 & - \\
FAUP4d & 2.69 & - \\
FAUP8d & 2.80 & - \\
GISC4d & 2.03 & 66.30 \\
GISC8d & 1.98 & 61.95 \\
\hline
\end{tabular}

* calculated by dry basis only for GIS zeolites obtained from Clinoptilolite.

Infrared vibrational spectroscopy provided additional information to confirm the synthesis of zeolites. The FTIR spectra of clinoptilolite and samples FAUP4d and GISC4d are shown in Figure 4. 


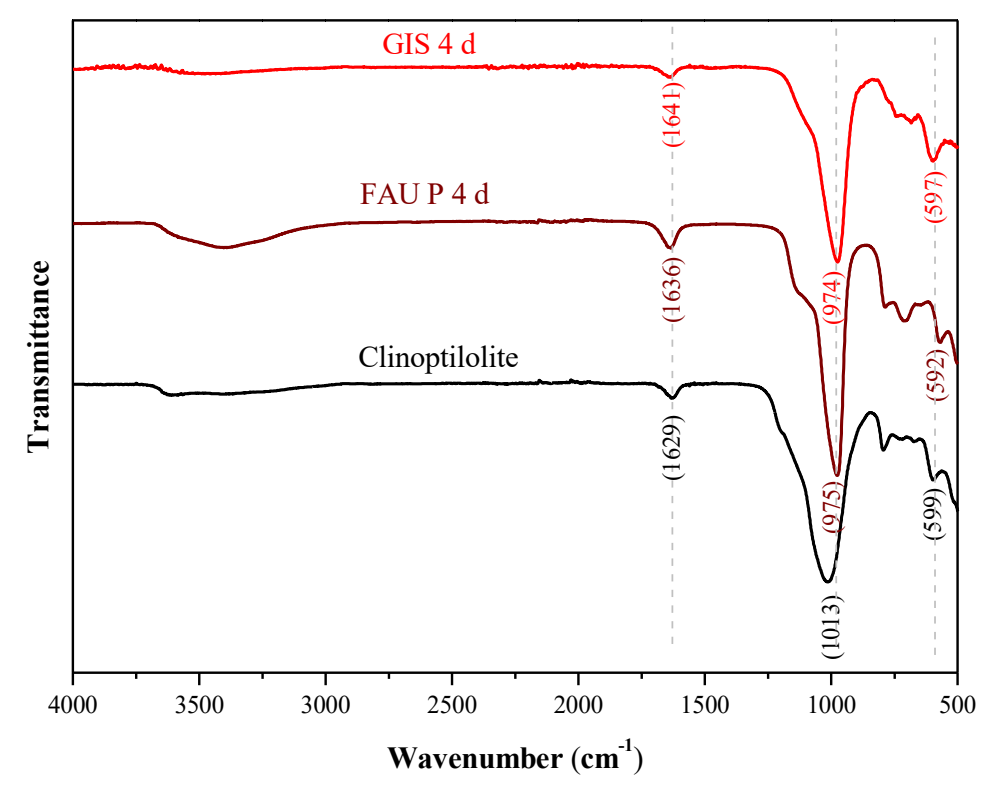

Figure 4. FTIR spectra of clinoptilolite, FAUP4d and GISC4d samples.

The band at $\sim 1630-1640 \mathrm{~cm}^{-1}$ is attributed to the bending vibration of $\mathrm{OH}$ groups in the adsorbed water and occurs for all materials. The band near $1000 \mathrm{~cm}^{-1}$ refers to an internal tetrahedral group insensible to structure. The bands in the region of 450 to $1000 \mathrm{~cm}^{-1}$ refer to the zeolite structure [40]. It was possible to observe some changes in these bands for the GIS4d and FAUP4d samples compared to the spectrum of clinoptilolite.

Scanning electron microscopy (SEM) images of clinoptilolite and GIS $4 \mathrm{~d}$ samples are shown in Figure 5. Figure 5A-C show that clinoptilolite has particles with a cluster morphology in the shape of irregular flakes (lamellar texture with a slightly amorphous appearance). On the other hand, the GIS $4 \mathrm{~d}$ sample (Figure 5D-F) shows a well-defined morphology of crystal clusters forming pseudo symmetrical structures (rounded octahedra with concave faces). These micrographs clearly show that this sample is very crystalline, as it is impossible to observe clinoptilolite particles or amorphous phases. This result follows the XRD results (Figure 3) (Table 2), where it was possible to observe the complete transformation of clinoptilolite into the GIS zeolite.

\subsection{LTA Zeolite Synthesis Using Clinoptilolite}

The diffractograms of the standard LTA zeolite (Figure 1) and the materials obtained with the synthesis using clinoptilolite (Figure 6) show that it was possible to obtain the LTA zeolite from clinoptilolite in 1 to $6 \mathrm{~h}$. The clinoptilolite phase is indicated by C, and Miller indices mark the LTA zeolite phase. The materials exhibit crystalline phases relative to the LTA zeolite, with narrow peaks and high intensity. The LTAC6h sample presented more defined peaks, with more phases belonging to LTA. In Figure 6, the $2 \theta$ peak at $8.8^{\circ}$ (marked with ${ }^{*}$ ) is an unidentified peak present in the clinoptilolite sample and synthesized materials.

Table 3 presents the FRX results from LTA-obtained materials and the clinoptilolite material. The materials are mainly aluminosilicates and contain other elements that are typical of natural zeolites, such as $\mathrm{K}, \mathrm{Fe}, \mathrm{Mg}, \mathrm{Ca}$, and $\mathrm{Na}$, with $\mathrm{Ca}$ and $\mathrm{Na}$ probably being the structure compensation cations. LTA standards have a high $\mathrm{Na}$ content and a $\mathrm{Si} / \mathrm{Al}$ ratio of $\sim 1.0$. Sodium is a principal compensation cation in the framework due to the $\mathrm{Al}$ content.

Table 4 shows the $\mathrm{Si}$ / Al molar ratio, relative crystallinity, and synthesis yield values for standard LTA zeolites and samples synthesized from clinoptilolite. The $\mathrm{Si} / \mathrm{Al}$ ratio and the relative crystallinity percentage decrease, and the synthesis yield increases as the synthesis time increases, which indicates that with the increase in the synthesis time, expansion of 
the LTA phase occurs, yielding more of the LTA zeolite. A decrease in the Si/Al ratio was already expected because the LTA zeolite has a $\mathrm{Si} / \mathrm{Al}$ ratio $=1.0$. Comparing the relative crystallinity values taking LTAP3h as the standard of $100 \%$, the synthesized materials exhibit lower crystallinity (above $32 \%$ ) and an increase in crystallinity with synthesis time. Thus, with increasing time, more of the LTA zeolite phase forms. These results are in line with the XRD results (Figure 6).

LTA materials obtained from clinoptilolite show that with increasing synthesis time, more of the LTA zeolite forms; consequently, the $\mathrm{Si} / \mathrm{Al}$ ratio is close to 1.0, and the $\mathrm{Na}$ content increases. Other elements from clinoptilolite probably remain in the materials as compensating cations.

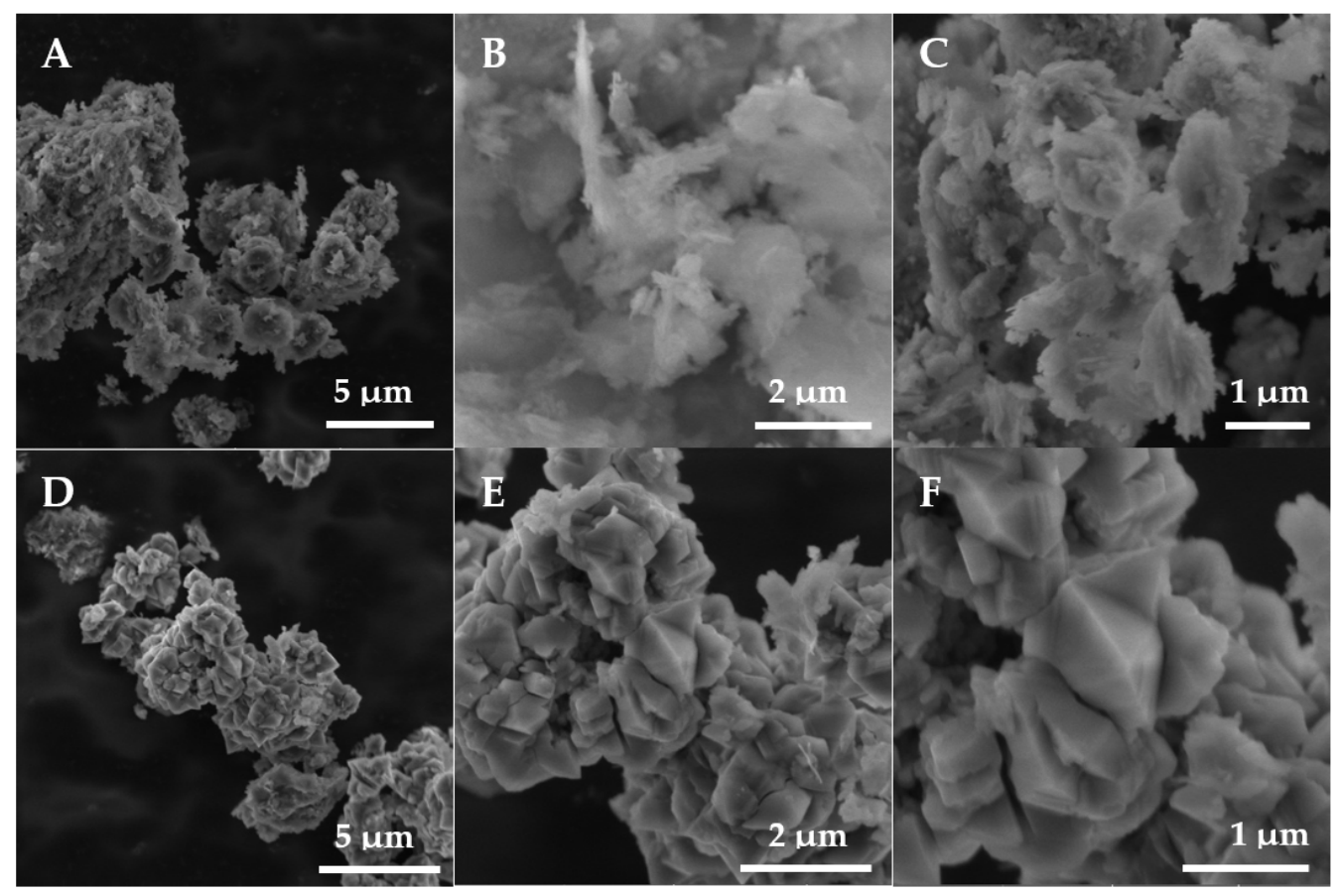

Figure 5. Micrographs of the clinoptilolite samples: (A) $5 \mu \mathrm{m}$ scale, (B) $2 \mu \mathrm{m}$ scale, and (C) $1 \mu \mathrm{m}$ scale. Micrographs of GISC4d: (D) $5 \mu \mathrm{m}$ scale, (E) $2 \mu \mathrm{m}$ scale, and (F) $1 \mu \mathrm{m}$ scale.

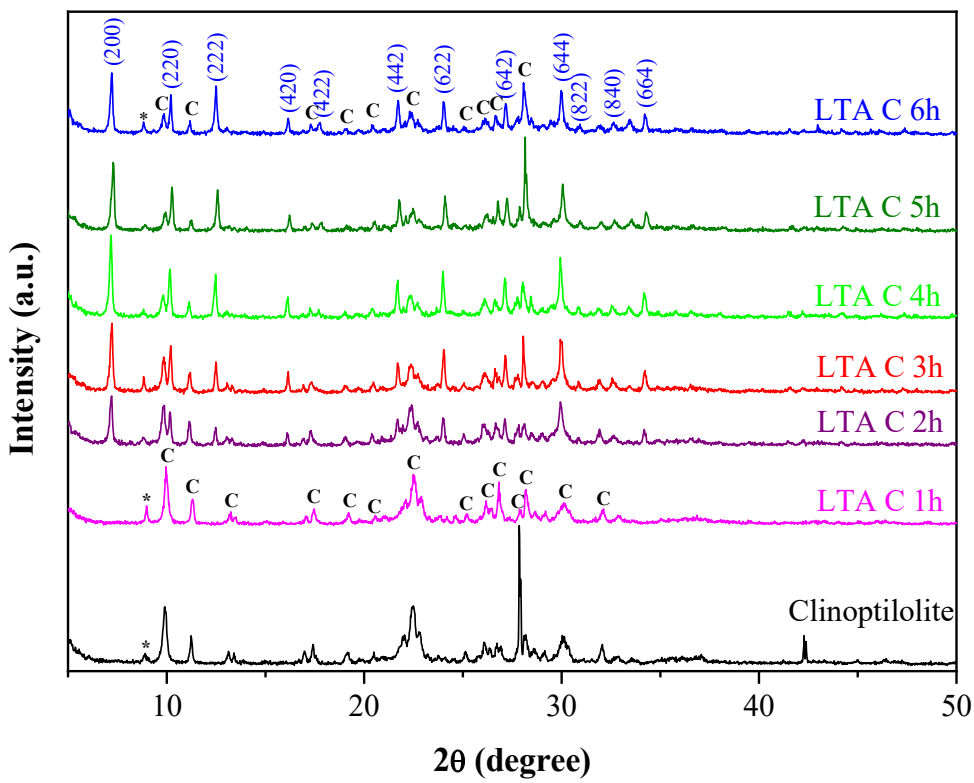

Figure 6. Diffractograms of LTA zeolites from clinoptilolite ( ${ }^{*}$ is an unidentified peak). 
Table 3. Chemical composition (FRX) of standard LTA zeolites and LTA zeolites from clinoptilolite.

\begin{tabular}{cccccccccc}
\hline Oxide & Clinoptilolite & LTA P3h & LTA P6h & LTA C1h & LTA C2h & LTA C3h & LTA C4h & LTA C5h & LTA C6h \\
\hline $\mathrm{SiO}_{2}(\%)$ & 72.29 & 48.39 & 48.05 & 69.84 & 59.32 & 56.18 & 52.80 & 53.35 \\
$\mathrm{Al}_{2} \mathrm{O}_{3}(\%)$ & 12.80 & 34.93 & 35.36 & 13.49 & 20.59 & 23.67 & 27.71 & 26.02 & 24.32 \\
$\mathrm{~K}_{2} \mathrm{O}(\%)$ & 4.47 & 0.05 & n.d. & 3.53 & 3.09 & 2.80 & 2.57 & 2.43 & 2.54 \\
$\mathrm{CaO}(\%)$ & 4.09 & n.d. & n.d. & 4.26 & 3.69 & 3.53 & 3.35 & 3.44 & 3.61 \\
$\mathrm{SO}_{3}(\%)$ & 0.12 & 0.15 & 0.19 & 0.15 & 0.12 & - & 0.13 & 0.19 & 0.25 \\
$\mathrm{Fe}_{2} \mathrm{O}_{3}(\%)$ & 2.30 & 0.05 & 0.04 & 2.15 & 1.98 & 1.93 & 1.82 & 1.78 \\
$\left.\mathrm{MgO}^{2} \%\right)$ & 2.10 & 1.30 & 1.40 & 2.00 & 2.30 & 1.70 & 2.20 & 1.70 & 1.85 \\
$\mathrm{Na}_{2} \mathrm{O}(\%)$ & 1.30 & 14.90 & 14.70 & 4.00 & 8.40 & 9.60 & 10.80 & 10.60 & 11.40 \\
Others (\%) & 0.53 & 0.21 & 0.21 & 0.58 & 0.53 & 0.54 & 0.55 & 0.54 & 0.62 \\
\hline
\end{tabular}

n.d. = not detected.

Table 4. Si / Al molar ratio values, relative crystallinity percentage, and synthesis yield of standard LTA zeolites and LTA zeolites from clinoptilolite.

\begin{tabular}{cccc}
\hline Sample & Ratio Si/Al & $\begin{array}{c}\text { \% Relative } \\
\text { Crystallinity }\end{array}$ & $\begin{array}{c}\text { Synthesis Yield \% } \\
(\mathbf{m} / \mathbf{m})\end{array}$ \\
\hline Clinoptilolite & 4.79 & - & - \\
LTAP3h & 1.17 & 100 & 64.79 \\
LTAP6h & 1.15 & n.c. & 61.46 \\
LTAC1h & 4.40 & 9.7 & 38.66 \\
LTAC2h & 2.45 & 20.1 & 38.67 \\
LTAC3h & 2.01 & 26.1 & 32.98 \\
LTAC4h & 1.61 & 32.0 & 41.19 \\
LTAC5h & 1.74 & 24.7 & 58.90 \\
LTAC6h & 1.86 & 27.3 & 63.73 \\
\hline
\end{tabular}

n.c. = not calculated.

The FTIR spectra of clinoptilolite and zeolite samples LTAP6h and LTA6h are shown in Figure 7. Comparison of these spectra shows that the synthesis of the LTA6h sample from clinoptilolite only slightly decreased peak intensities and slightly displaced bands compared to the LTAP6h zeolite. The 976,661 , and $444 \mathrm{~cm}^{-1}$ bands of the LTAC6h sample are very close to the 964,666 , and $459 \mathrm{~cm}^{-1}$ bands of the LTAP6h zeolite and are attributed to the asymmetric elongation vibration of the internal tetrahedra, symmetric elongation vibrations, and the flexural vibration modes of $\mathrm{TO}$ bonds in $\mathrm{TO}_{4}$ tetrahedra (where $\mathrm{T}=\mathrm{Si}$ or $\mathrm{Al}$ ), respectively [40]. The band close to $551 \mathrm{~cm}^{-1}$ is due to D4R, which is the main secondary construction unit in the LTA zeolite [42], and the band at $1637 \mathrm{~cm}^{-1}$ is attributed to the bending vibration of the $\mathrm{OH}$ group in the adsorbed water [40]. The bands in the region of 450 to $1000 \mathrm{~cm}^{-1}$ from the LTA materials occur in different positions and with different intensities than the bands of clinoptilolite, indicating a change in structure.

The LTAC6h sample (Figure 8A-C) presents a cubic particle morphology characteristic of LTA-type zeolites. This sample also exhibits a particle morphology similar to that of the clinoptilolite zeolite, which agrees with the XRD results (Figure 6) and the crystallinity (Table 4), indicating a longer synthesis time is needed to obtain pure LTA. 


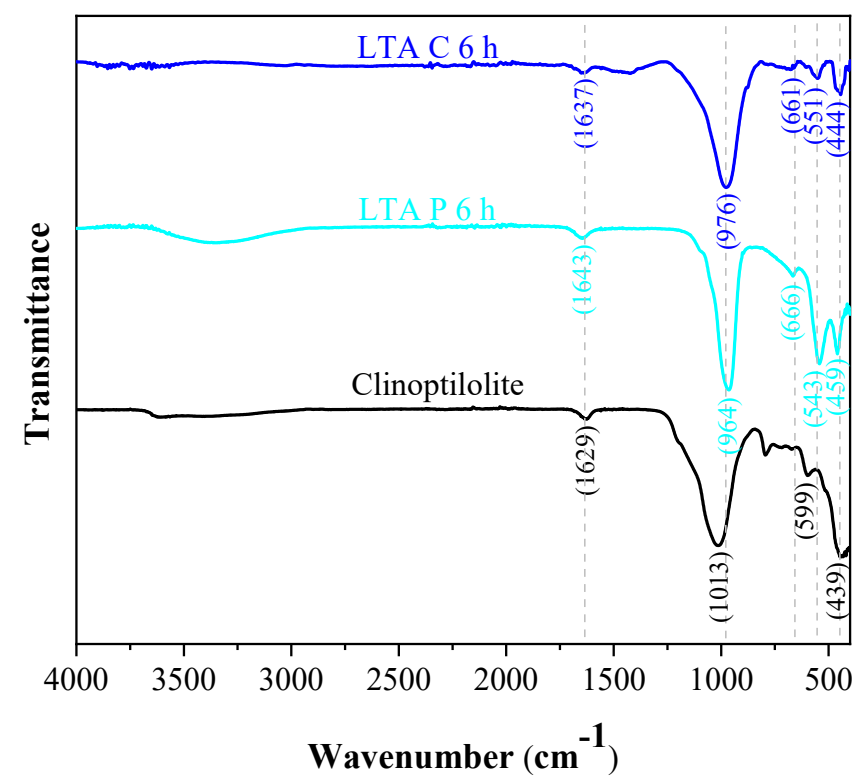

Figure 7. FTIR spectra of clinoptilolite and the LTAP6h and LTAC6h zeolite samples.
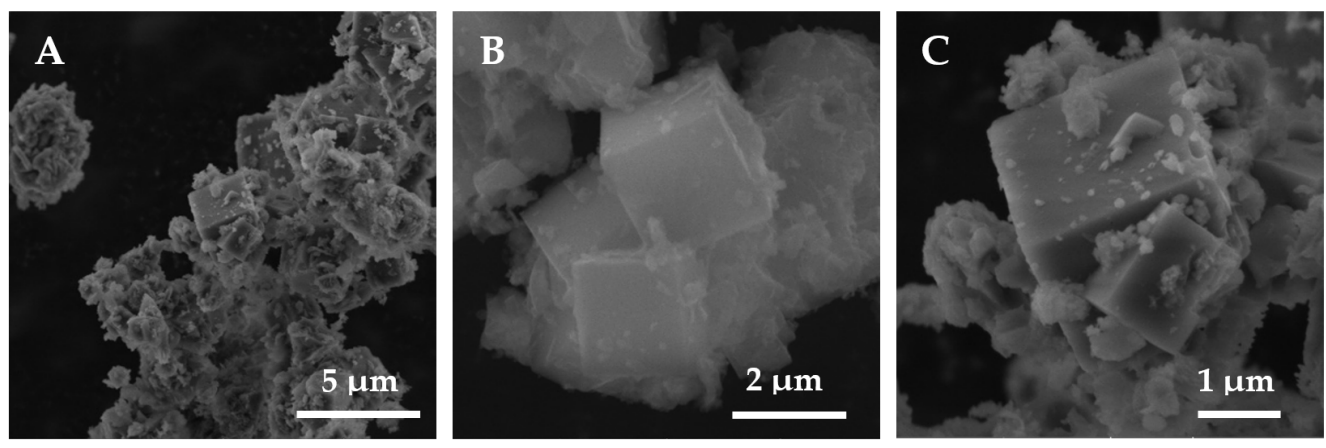

Figure 8. Micrograph of the LTA C 6 h samples: (A) $5 \mu \mathrm{m}$ scale, (B) $2 \mu \mathrm{m}$ scale, and (C) $1 \mu \mathrm{m}$ scale.

\section{Discussion}

In this work, we propose the interzeolitic transformation of clinoptilolite into LTA and GIS zeolites. Intezeolitic transformation is possible because zeolites are metastable phases controlled kinetically by the transformation of silicates. Therefore, according to the Ostwald rule, it is possible to convert one phase into another more densely [41]. However, in the literature, some cases of the transformation of the zeolitic dense phase are less dense [43].

From the results of this work, FAU standard synthesis gives the FAU structure, as proved by XRD analysis; however, when the clinoptilolite was used as Si and Al sources, the structure obtained was GIS, which XRD also confirmed. It is well known that the GIS phase is a more stable phase than FAU, and it can be obtained from FAU (see Figure 9 from the work of Maldonado et al., 2013 [44], which represents this transformation).

When clinoptilolite was used as the raw material for FAU synthesis, the accelerated transformation to more stable phases occurred, leading to the GIS phase. If clinoptilolite dissolves in basic media, forming $\mathrm{TO}_{4}$ units, these units can be rearranged, leading to a new topology such as FAU and its transformation to the GIS phase. On the other hand, if the clinoptilolite (HEU topology) phase did not dissolve completely and C4 units (RBUs) remained, transformation into the GIS topology was possible without passing through the FAU phase. However, initial synthesis times did not give the FAU phase, so the second mechanism is probably occurring.

LTA synthesis can occur in two ways: by dissolving clinoptilolite and forming the LTA structure by $\mathrm{TO}_{4}$ rearrangement and by intracrystalline transformation using the C4 RBUs from clinoptilolite (HEU). 


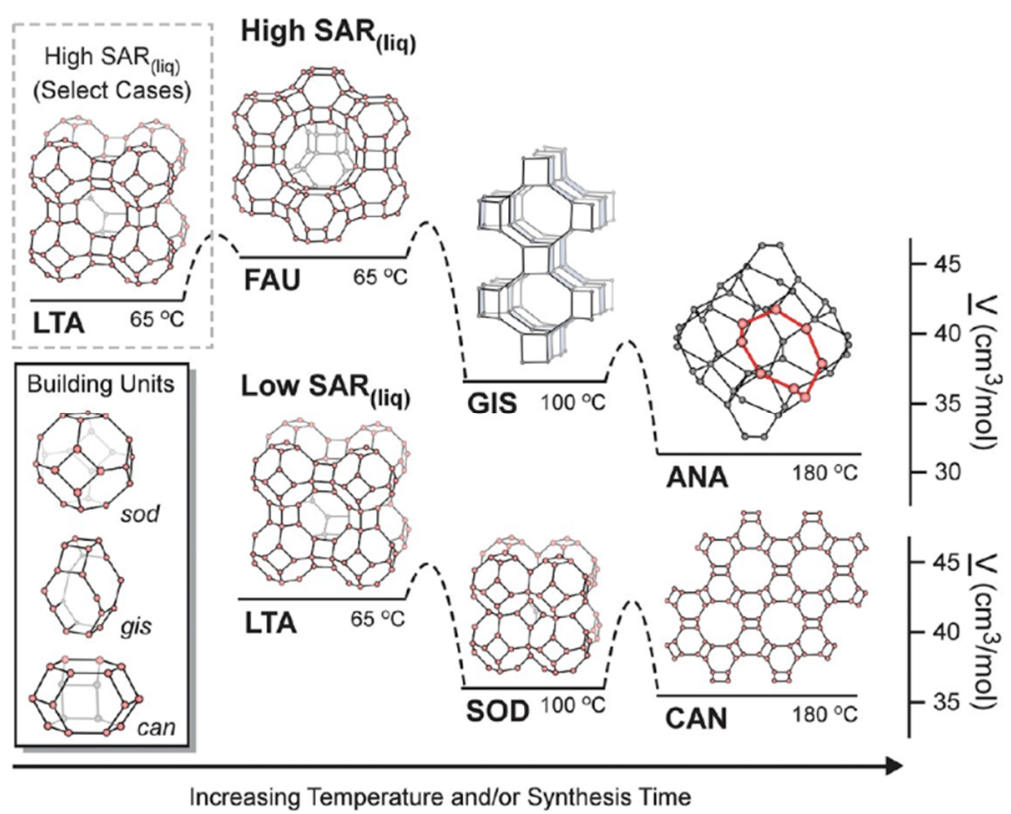

Figure 9. Stages of Na-zeolite phase transformation with increasing synthesis temperature and time. (adapted from [44]).

This mechanistic route for intracrystalline zeolites was proposed by Itabashi et al. in 2012 [45]. In this way, crystallization of the zeolite occurs when the materials have the same CBU (Composite Building Unit) from the pristine zeolite [46]. This is in accordance with some transformations, such as FAU, LTA, and SOD [44], because these topologies have the same CBU (sod) in their frameworks. Nonetheless, FAU to GIS transformation does not have the same CBUs, indicating that, for this transformation, this factor is not as important. Suhendar et al. 2018 [47] studied the influence of framework density and the CBU (Composite Building Unit), SBU (Secondary Building Unit), and RBU (Ring Building Unit). In this study, the authors show that zeolitic fragments or dissolved silica rarely match CBUs. The CBUs have many $\mathrm{T}$ atoms. Thus, the significant influence will be from SBUs and RBUs. The authors propose the RBUs as the approach that is more adequate to understand the interzeolitic transformation.

In this work, the RBU approaches are more adequate because HEU, GIS, and LTA have C4 RBUs. Figure 10 shows the material structures with CBU, SBU, RBU, and framework density. The HEU topology is a denser structure than other material structures. Usually, it is expected that transformation leads to more stable and dense structures. This occurs with the transformation of the FAU topology to GIS. However, it is possible to undergo interzeolite transformation to phases that are less dense; one example is transforming the FAU topology into HEU [48]. The LTA and FAU topologies have the same CBUs and SBUs; however, for HEU and LTA or GIS, their CBUs and SBUs are different. On the other hand, all materials have at least four RBUs, with some having six.

A priori, both paths (total dissolution forming $\mathrm{TO}_{4}$ or partial dissolution forming SBUs and RBUs) can occur for this interzeolitic transformation. Still, considering the clinoptilolite material, which has a great variety of cations on its structure, more than one zeolitic phase can appear in the total dissolution pathway. Furthermore, it is well known that cations with water solvation act as SDA-forming zeolite structures. Thus, the mechanism of intracrystalline zeolite transformation using RBUs is more adequate to explain our results. 

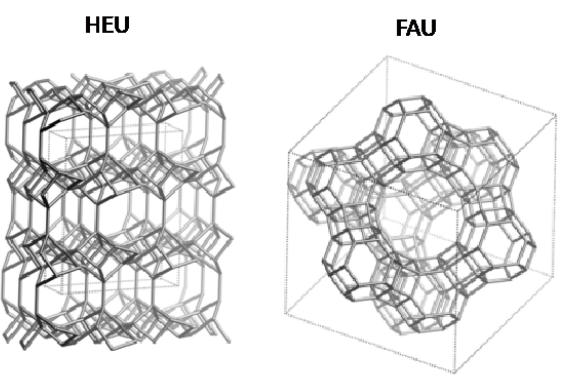

ITA
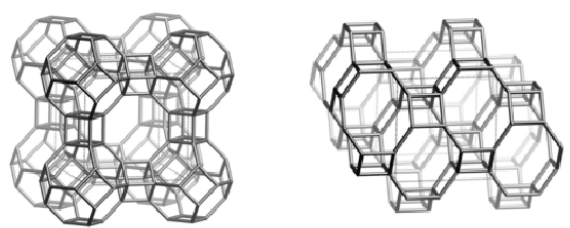

\begin{tabular}{|c|c|c|c|c|}
\hline RBU & 4 or 6 & 4 or 6 & 4 or 6 & 4 \\
\hline SBU & $4-4=1$ & $\begin{array}{l}6-6 \text { or } 6-2 \text { or } 6 \text { or } 4-2 \text { or } 1-4- \\
1 \text { or } 4\end{array}$ & 8 or $4-4$ or $6-2$ or 6 or $1-4-1$ or 4 & 8 or 4 \\
\hline CBU & bre & $d \sigma r^{-}$ & $d 4 r$ & \\
\hline FD & $17.1 \mathrm{~T} / 1000 \mathrm{~A}^{3}$ & $12.7 \mathrm{~T} / 1000 \bar{A}^{3}$ & $12.9 \mathrm{~T} / 1000 \AA^{3}$ & $15.3 \mathrm{~T} / 1000 \dot{A}^{3}$ \\
\hline
\end{tabular}

Figure 10. Zeolite HEU, FAU, LTA, and GIS structures with RBU, SBU, CBU, and framework density (data from IZA [39]).

\section{Conclusions}

The interzeolitic transformation of clinoptilolite into GIS and LTA zeolites occurred under the studied conditions. The results reveal that a synthesis reaction time of 4 days was enough to obtain the structure of the GIS zeolite, and more than $4 \mathrm{~h}$ could be used to obtain the LTA zeolite.

The mechanism of interzeolitic transformation has not yet been elucidated, but the results point to the approach of intracrystalline transformation using the C4 RBUs from clinoptilolite (HEU).

The use of clinoptilolite as an alternative source of silicon and aluminum in the synthesis of zeolites is an innovative, economically viable, and environmentally correct process that exploits a material that exists in large quantities and is still little explored industry.

Author Contributions: Conceptualization, S.B.C.P.; methodology, R.C.F.d.L. and D.d.S.O. validation, R.C.F.d.L.; formal analysis, R.C.F.d.L., D.d.S.O. and S.B.C.P.; investigation, R.C.F.d.L., D.d.S.O. and S.B.C.P.; resources, S.B.C.P.; data curation, D.d.S.O.; writing-original draft preparation, R.C.F.d.L.; writing-review and editing, S.B.C.P.; supervision, D.d.S.O. and S.B.C.P.; project administration, S.B.C.P. All authors have read and agreed to the published version of the manuscript.

Funding: This study was financed in part by the Coordenação de Aperfeiçoamento de Pessoal de Nível Superior-Brasil (CAPES)-Finance Code 001.

Acknowledgments: Thank you to Celta Brasil for the clinoptilolite sample.

Conflicts of Interest: The authors declare no conflict of interest.

\section{References}

1. Armbruster, T.; Gunter, M.E. Crystal Structures of Natural Zeolites. Rev. Min. Geo. 2001, 45, 1-67. [CrossRef]

2. Bish, D.L.; Boak, J.M. Clinoptilolite-Heulandite Nomenclature. Rev. Min. Geo. 2001, 45, 207-216. [CrossRef]

3. Colella, C.; Wise, W.S. The Iza Handbook of Natural Zeolites: A tool of knowledge on the most important family of porous minerals. Micro. Meso. Mat. 2014, 189, 4-10. [CrossRef]

4. Kocak, Y.; Tasci, E.; Kaya, U. The effect of using natural zeolite on the properties and hydration characteristics of blended cements. Constr. Build. Mater. 2013, 47, 720-727. [CrossRef]

5. Seryotkin, Y.V. High-pressure behavior of HEU-type zeolites: X-ray diffraction study of clinoptilolite-Na. Micro. Meso. Mat. 2016, 235, 20-31. [CrossRef]

6. Aksoy, Y.Y. Characterization of two natural zeolites for geotechnical and geoenvironmental applications. Appl. Clay Sci. 2010, 50, 130-136. [CrossRef]

7. Braga, A.A.C.; Morgon, N.H. Descrições estruturais cristalinas de zeólitos. Quím. Nova. 2007, 30, 178-188. [CrossRef] 
8. Valpotic, H.; Gracner, D.; Turk, R.; Duricic, D.; Vince, S.; Folnozic, I.; Lojkic, M.; Zaja, I.Z.; Bedrica, L.; Macesic, N.; et al. Zeolite clinoptilolite nanoporous feed additive for animals of veterinary importance: Potencials and limitations. Periodicum. Biologorum. 2017, 119, 159-172. [CrossRef]

9. Bessa, R.A.; Costa, L.S.; Oliveira, C.P.; Bohn, F.; Nascimento, R.F.; Sasaki, J.M.; Loiola, A.R. Kaolin-based magnetic zeolites A and P as water softeners. Micro. Meso. Mat. 2017, 245, 64-72. [CrossRef]

10. Du, Y.; Shi, S.; Dai, H. Water-bathing synthesis of high-surface-area zeolite P from diatomite. Particuology 2011, 9, 174-178. [CrossRef]

11. Nascimento, C.R.; Sobrinho, E.M.O.; Assis, R.B.; Fagundes, R.F.; Bieseki, L.; Pergher, S.B.C. Síntese da Zeólita A utilizando diatomita como fonte de sílicio e alumínio. Cerâmica 2014, 60, 63-68. [CrossRef]

12. Silva Filho, S.H.; Bieseki, L.; Silva, A.R.; Maia, A.A.B.; Gil San, R.A.S.; Pergher, S.B.C. Synthesis of Zeolite A employing Amazon kaolin waste. Cerâmica 2015, 61, 409-413. [CrossRef]

13. Menezes, R.A.; Paz, S.P.A.; Angélica, R.S.; Neves, R.F.; Pergher, S.B.C. Color and shade parameters of ultramarine zeolitic pigments synthesized from kaolin waste. Mat. Res. 2014, 17, 23-27. [CrossRef]

14. Schwanke, A.J.; Spazzini, S.T.; Penha, F.G.; Pergher, S.B.C. Síntese da zeóita Cancrenita a partir de Caulim: Uma alternativa viável à redução de impactos ambientais. Tecnology 2011, 15, 11-14.

15. Rigo, R.T.; Pergher, S.B.C.; Petkowicz, D.I.; Santos, J.H.Z. Um novo procedimento de sintese da zeolita A empregando argilas naturais. Quím. Nova. 2009, 32, 21-25. [CrossRef]

16. Mignoni, M.L.; Petkowicz, D.I.; Machado, N.R.C.F.; Pergher, S.B.C. Synthesis of mordenite using kaolin as Si and Al source. Appl. Clay Sci. 2008, 41, 99-104. [CrossRef]

17. Mignoni, M.L.; Detoni, C.; Pergher, S.B.C. Estudo da Síntese da Zeólita ZSM-5 a partir de Argilas Naturais. Quím. Nova 2007, 30, 45-48. [CrossRef]

18. Menezes, R.A.; Paz, S.P.A.; Angélica, R.S.; Neves, R.F.; Neumann, R.; Faulstich, F.R.L.; Pergher, S.B.C. Synthesis of ultramarine pigments from Na-A zeolite derived from kaolin waste from the Amazon. Clay Min. 2017, 52, 83-95. [CrossRef]

19. Silva Filho, S.H.; Bieseki, L.; Maia, A.A.B.; Treichel, H.; Angelica, R.S.; Pergher, S.B.C. Study on the NaOH/metakaolin Ratio and Crystallization Time for Zeolite a Synthesis from Kaolin Using Statistical Design. Mat. Res. 2017, 20, 761-767. [CrossRef]

20. Behin, J.; Kazemian, H.; Rohani, S. Sonochemical synthesis of zeolite NaP from clinoptilolite. Ultra Sonochem. 2016, 28, 400-408. [CrossRef]

21. Tatlier, M.; Atalay-Oral, C. Crystallization od Zeolite A Coatings from Natural Zeolite. Mat. Res. 2016, 19, 1469-1477. [CrossRef]

22. Silva Filho, S.H.; Vinaches, P.; Silva, H.L.G.; Pergher, S.B.C. LTA zeolite synthesis using natural materials and its evaluation by Green Star methodology. SN Appl. Sci. 2020, 2, 344. [CrossRef]

23. Vinaches, P.; Schwanke, A.J.; Lopes, C.W.; Souza, I.M.S.; Villarroel-Rocha, J.; Sapag, K.; Pergher, S.B.C. Incorporation of Brazilian Diatomite in the Synthesis of An MFI Zeolite. Molecules 2019, 24, 1980. [CrossRef]

24. Collins, F.; Rozhkovskaya, A.; Outram, J.G.; Millar, G.J. A critical review of waste resources, synthesis, and applications for zeolite LTA. Micro. Meso. Mat. 2019, 291, 109667. [CrossRef]

25. Silva Filho, S.H.; Vinaches, P.; Pergher, S.B.C. Zeolite synthesis in basic media using expanded perlite and its application in Rhodamine B adsorption. Mat. Lett. 2018, 227, 258-260. [CrossRef]

26. Oliveira, M.S.M.; Nascimento, R.M.; Pergher, S.B.C. Síntese de zeolita LPM-12 (tipo EDI) utilizanto resíduo do processamento do espodumênio como fonte alternativa de silício e Alumínio. Rev. Persp. 2018, 42, 119-125.

27. Vinaches, P.; Alves, J.A.B.L.R.; Melo, D.M.A.; Pergher, S.B.C. Raw powder glass as a silica source in the synthesis of colloidal MEL zeolite. Mat. Lett. 2016, 178, 217-220. [CrossRef]

28. Vinaches, P.; Rebitski, E.P.; Alves, J.A.B.L.R.; Melo, D.M.A.; Pergher, S.B.C. Unconventional silica source employment in zeolite synthesis: Raw powder glass in MFI synthesis case study. Mat. Lett. 2015, 159, 233-236. [CrossRef]

29. Alves, J.A.B.L.R.; Dantas, E.R.S.; Pergher, S.B.C.; Melo, D.M.A.; Melo, M.A.F. Synthesis of high value-added zeolitic materials using glass powder residue as a silica source. Mat. Res. 2014, 17, 213-218. [CrossRef]

30. Bieseki, L.; Ribeiro, D.B.; Sobrinho, E.V.; Melo, D.M.A.; Pergher, S.B.C. Síntese de zeólitas utilizando resíduo sílico-aluminoso proveniente do processo de extração de lítio. Cerâmica 2013, 59, 466-472. [CrossRef]

31. Lima, G.C.C.S.; Mello, M.I.S.; Araujo, A.S.; Pergher, S.B.C. Hydrothermal Synthesis of Silicoaluminophsphate with AEL structure using residue of fluorescent lamps as starting material. Molecules 2021. under revision.

32. Cruz, T.J.T.; Melo, M.I.S.; Pergher, S. Optimization of Parameters and Methodology for the Synthesis of LTA-Type Zeolite Using Light Coal Ash. Appl. Sci. 2020, 10, 7332. [CrossRef]

33. Tomaszewska, B.; Kmiecik, E.; Wator, K.; Tyszer, M. Use of numerical modelling in the prediction of membrane scaling. Reaction between antiscalants and feedwater. Desalination 2018, 427, 27-34. [CrossRef]

34. Meshram, S.U.; Khandekar, U.R.; Mane, S.M.; Mohan, A. Novel Route of Producing Zeolite A Resin for Quality-Improved Detergents. J. Sufact. Deterg. 2015, 18, 259-266. [CrossRef]

35. Liu, Y.; Wang, G.; Wang, L.; Li, X.; Luo, Q.; Na, P. Zeolite P synthesis based on fly ash and its removal of Cu (II) and Ni (II) ions. Chin. J. Chem. Eng. 2019, 27, 341-348. [CrossRef]

36. Shun, K.D.; Lin, L.; Xin, F.J.; Hua, J.Y.; Zhi, L. Preparation of P type molecular sieves from gangue of high iron and high silica content. Bull. Chin. Ceram. Soc. 2013, 32, 1052-1056.

37. Cardoso, A.M.; Horn, B.M.; Ferret, L.S.; Azevedo, C.M.N.; Pires, M. Integrated synthesis of zeolites 4A and Na-P1 using coal fly ash for application in the formulation of detergents and swine wastewater treatment. J. Haz. Mat. 2015, 287, 69-77. [CrossRef] 
38. Celta Brasil. Available online: www.celtabrasil.com.br (accessed on 10 July 2021).

39. IZA-International Zeolite Association. Available online: www.iza-structure.org (accessed on 10 July 2021).

40. Giannetto, G.P.; Montes, A.R.; Rodriguíguez, G.F. Zeolitas-Características, Propiedades y Aplicaciones Industriales, 2nd ed.; Editorial Innovación Tecnológica: Caracasm, Venezuela, 2000.

41. Goel, S.; Zones, S.I.; Iglesia, E. Encapsulation of metal clusters within MFI via interzeollite transformations and direct hydrothetmal ssynthesis and catalitic consequences of theis confinement. JACS 2014, 136, 15280-15290. [CrossRef] [PubMed]

42. Pan, M.; Li, P.; Zheng, J.; Liu, Y.; Kong, Q.; Tian, H.; Li, R. Zeolite-zeolite composite composed of Y zeolite and single-crystal-like ZEM-5 zeolite: Fabricated by a process like "big fish swallowing little one". Mater. Chem. Phys. 2017, 194, 49-54. [CrossRef]

43. Goto, I.; Itakura, M.; Shibata, S.; Honda, K.; Ide, Y.; Sadakane, M.; Sato, T. Transformation of LEV-type zeolite into less dense CHA-type zeolite. Micro. Meso. Mat. 2012, 158, 117-122. [CrossRef]

44. Maldonano, M.; Oleksiak, M.D.; Chinta, S.; Rimer, J.D. Controlling crystal polymorphism in organic-free synthesis of Na-zeolites. JACS 2013, 135, 2641-2652. [CrossRef] [PubMed]

45. Itabashi, K.; Kamimura, Y.; Iyoki, K.; Shimojima, A.; Okubo, T. Working hypothesis for broadening framework types zeolites in seed-assisted synthesis without organic strcturure-directing agent. JACS 2012, 134, 11542-11549. [CrossRef] [PubMed]

46. Isobe, M.; Moteki, T.; Tanagashi, S.; Kimura, R.; Kamimura, Y.; Itabashi, K.; Okubo, T. Plate-like precursors formed in crystallization process of ferrierite drom (Na, K) aluminosilicate system. Micro. Meso. Mat. 2012, 158, 204-208. [CrossRef]

47. Suhendar, D.; Mukti, R.R. Simple approach in understanding interzeolite transofrmations using ring building units. IOP Conf. Ser. Mat. Sci. Eng. 2018, 349, 012016. [CrossRef]

48. Davis, O.C.M.E. Hydrothermal conversion of Y-zeolite using alkaline earth cations. Micro. Meso. Mat. 1999, 32, 257-264. [CrossRef] 